\title{
Cannabinoid Receptors in the Central Nervous System: Their Signaling and Roles in Disease
}

\author{
Debra A. Kendall ${ }^{1}$ and Guillermo A. Yudowski ${ }^{2,3 *}$ \\ ${ }^{1}$ Department of Pharmaceutical Sciences, University of Connecticut, Storrs, CT, USA, ${ }^{2}$ Department of Anatomy and \\ Neurobiology, University of Puerto Rico, Medical Sciences Campus, San Juan, Puerto Rico, ${ }^{3}$ Institute of Neurobiology, \\ University of Puerto Rico, San Juan, Puerto Rico
}

The identification and cloning of the two major cannabinoid $\left(\mathrm{CB}_{1}\right.$ and $\left.\mathrm{CB}_{2}\right)$ receptors together with the discovery of their endogenous ligands in the late 80s and early 90s, resulted in a major effort aimed at understanding the mechanisms and physiological roles of the endocannabinoid system (ECS). Due to its expression and localization in the central nervous system (CNS), the $\mathrm{CB}_{1}$ receptor together with its endogenous ligands (endocannabinoids (eCB)) and the enzymes involved in their synthesis and degradation, has been implicated in multiple pathophysiological events ranging from memory deficits to neurodegenerative disorders among others. In this review, we will provide a general overview of the ECS with emphasis on the $\mathrm{CB}_{1}$ receptor in health and disease. We will describe our current understanding of the complex aspects of receptor signaling and trafficking, including the non-canonical signaling pathways such as those mediated by $\beta$-arrestins within the context of functional selectivity and ligand bias. Finally, we will highlight some of the disorders in which $\mathrm{CB}_{1}$ receptors have been implicated. Significant knowledge has been achieved over the last 30 years. However, much more research is

OPEN ACCESS

Edited by: Hansen Wang, University of Toronto, Canada

Reviewed by: Carla Cannizzaro, University of Palermo, Italy Eilís Dowd, National University of Ireland, Galway, Ireland

${ }^{*}$ Correspondence: Guillermo A. Yudowski guillermo.yudowski@upr.edu

Received: 29 August 2016 Accepted: 08 December 2016 Published: 04 January 2017

Citation:

Kendall DA and Yudowski GA (2017) Cannabinoid Receptors in the Central Nervous System: Their Signaling and Roles in Disease. Front. Cell. Neurosci. 10:294. doi: 10.3389/fncel.2016.00294 still needed to fully understand the complex roles of the ECS, particularly in vivo and to unlock its true potential as a source of therapeutic targets.

Keywords: $\mathrm{CB}_{1}$ receptors, signaling, endocannabinoid system, neuromodulation, $\Delta^{9}-\mathrm{THC}$

\section{INTRODUCTION}

The endocannabinoid system (ECS) plays key modulatory roles during synaptic plasticity and homeostatic processes in the brain. Based on anecdotal evidence obtained from cannabis use, laboratory studies, and from emerging clinical work, modulation of the ECS has been proposed as a promising therapeutic target to treat numerous central nervous system (CNS) disorders including neurodegenerative diseases, epilepsy and cognitive deficits among others (Scotter et al., 2010; Fernández-Ruiz et al., 2011; Bilkei-Gorzo, 2012). However, the widespread expression and complex roles of several components of the ECS in excitatory and inhibitory transmission makes the development of such therapy highly challenging (Di Marzo, 2008).

This review will explore some of the relationships between the cannabinoid $\left(\mathrm{CB}_{1}\right.$ and $\left.\mathrm{CB}_{2}\right)$ receptors and their ligands with the nervous system in health and disease. We will introduce the

Abbreviations: AD, Alzheimer's Disease; AEA, arachidonylethanolamine; 2-AG, 2-arachidonoylglycerol; $\mathrm{CB}_{1}$ receptors, cannabinoid 1 receptor; $\mathrm{CB}_{2}$ receptor, cannabinoid 2 receptor; $\mathrm{CBD}$, cannabidiol; $\mathrm{CBs}$, synthetic ligands for $\mathrm{CB} 1 / 2$; CNS, central nervous system; eCBs, endocannabinoids; GPCR, G protein-coupled receptor; HD, Huntington's disease; MS, multiple sclerosis; TBI, traumatic brain injury. 
two major receptors, focusing on the $\mathrm{CB}_{1}$ receptors due to their high expression levels in the CNS; their endogenous ligands or endocannabinoids (eCB) and some synthetic mimetics that activate and modulate their signaling; the signaling pathways that connect this receptor to processes inside the cell; and the role of the $\mathrm{CB}$ system in the normally functioning CNS and its alteration or therapeutic modulation in a variety of disease states.

\section{$\mathrm{CB}_{1}$ RECEPTORS}

The $\mathrm{CB}_{1}$ receptor is one of the most abundant $\mathrm{G}$ protein-coupled receptors (GPCRs) in the CNS and is found in particularly high levels in the neocortex, hippocampus, basal ganglia, cerebellum and brainstem (Herkenham et al., 1991; Marsicano and Kuner, 2008). $\mathrm{CB}_{1}$ receptors are also found on peripheral nerve terminals and some extra-neural sites such as the testis, eye, vascular endothelium and spleen. Interestingly, $\mathrm{CB}_{1}$ receptors are highly enriched at presynaptic and axonal compartments, restricting their function to sites of synaptic activity (Straiker and Mackie, 2005; Wu et al., 2008). In addition to its location on the cell surface, intracellular localization of $\mathrm{CB}_{1}$ receptors has also been reported in heterologous systems and primary cultures (Leterrier et al., 2006; Rozenfeld, 2011). The $\mathrm{CB}_{1}$ receptor binds the main active ingredient of Cannabis sativa (marijuana), $\Delta^{9}$-tetrahydrocannabinol $\left(\Delta^{9}\right.$-THC) and mediates most of the CNS effects of $\Delta^{9}$-THC (Zimmer et al., 1999). In addition, $\mathrm{CB}_{1}$ receptors bind synthetic cannabimimetic compounds such as CP55940, JWH-015, WIN55212-2 and the endogenous arachidonic acid derivatives arachidonylethanolamine (AEA) and 2-arachidonylglycerol (2-AG; see below; Howlett et al., 2002). Upon ligand binding and receptor activation, $\mathrm{CB}_{1}$ receptors are primarily coupled to pertussis toxin (PTX)sensitive Gi/o type $G$ proteins which leads to a rapid decrease in levels of cAMP by inhibiting adenylate cyclase activity (Figure 1A; Howlett et al., 2004). Coupling to other G proteins including Gs, albeit with low efficacy, can also stimulate adenylate cyclase (Glass and Felder, 1997; Glass and Northup, 1999; Varga et al., 2008; Bosier et al., 2010) though the extent of accumulation of cAMP is not necessarily a good indicator of $\mathrm{G}$ protein coupling (Eldeeb et al., 2016). Evidence of promiscuous coupling to different $G$ proteins, signaling roles mediated by $\beta$-arrestins and signaling from intracellular compartments (Figure 1B) adds yet another level of complexity making these receptors, like other GPCRs, pluridimentional (Bosier et al., 2010). For our recent review on the multiple waves of receptor signaling see Nogueras-Ortiz and Yudowski (2016). $\mathrm{CB}_{1}$ receptors exhibit constitutive activity indicative of $G$ protein activation in the absence of agonists and this could mediate their highly polarized localization to axonal and presynaptic compartments (Bouaboula et al., 1997; Nie and Lewis, 2001; Rozenfeld, 2011). The activity associated with this state is reversed by treatment with inverse agonists such as SR141716A (also called rimonabant). The model for GPCR activation has been adapted to include these multiple states (Perez and Karnik, 2005; Park et al., 2008) with distinguishing biochemical characteristics, including extent and selectivity of G protein coupling (Mukhopadhyay and Howlett, 2001; Kenakin,

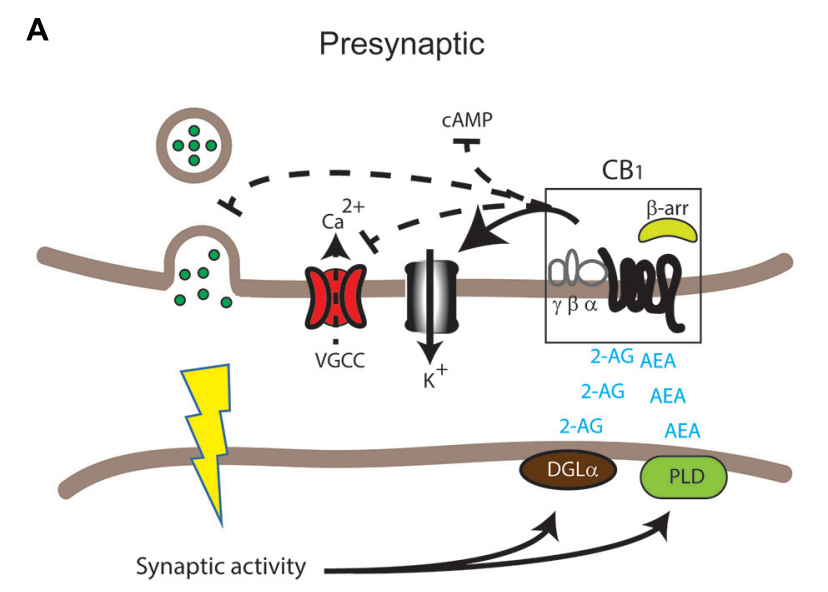

Postsynaptic

B

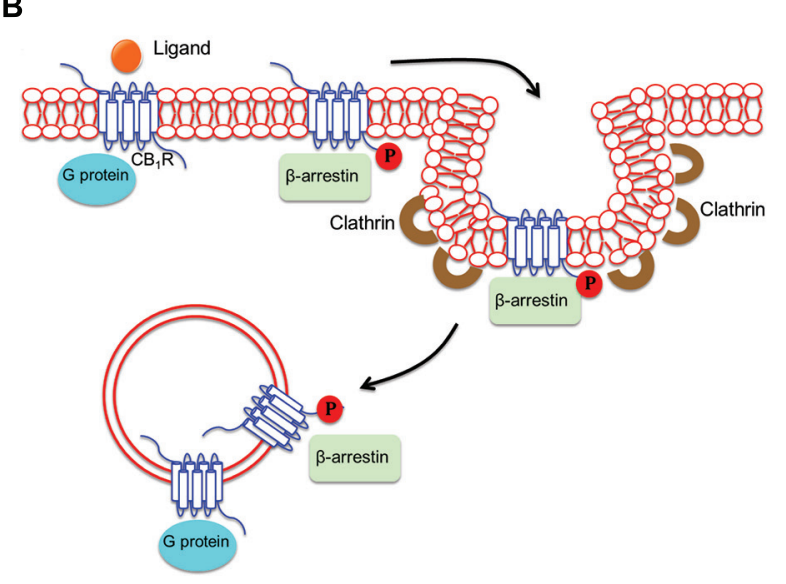

FIGURE 1 | Differential cannabinoid (CB) receptor signaling modalities can impact neuromodulation in health and disease in specific ways. (A) Key enzymes such as diacylglycerol lipase (DGL $\alpha$ ) and phospholipase D (PLD) produce the endogenous ligands arachidonylethanolamine (AEA) and 2-arachidonylglycerol (2-AG). These activate the cannabinoid 1 receptor $\left(\mathrm{CB}_{1}\right)$ receptor in the central nervous system (CNS). The result can include modulation of adenylate cyclase activity to inhibit CAMP accumulation, voltage-gated calcium channels (VGCC), K+ channels and neurotransmitter release in presynaptic excitatory and inhibitory synapses. (B) Following activation of the $\mathrm{CB}_{1}$ receptor by ligand binding, signaling via $\mathrm{G}$ protein and/or $\beta$-arrestin may occur at the plasma membrane, in endocytic pits or in endosomes after internalization of the receptor. $G$ proteins usually bind the unphosphorylated receptor while $\beta$-arrestin binds the receptor phosphorylated by $\mathrm{G}$ protein receptor kinases.

2004). The recent crystallization of the $\mathrm{CB}_{1}$ receptor bound to the antagonist AM6538, should provide new opportunities for understanding the structure-function relationship of this receptor and help novel drug design (Hua et al., 2016).

\section{$\mathrm{CB}_{2}$ RECEPTORS}

The $\mathrm{CB}_{2}$ receptor exhibits a more defined pattern of expression in the brain than $\mathrm{CB}_{1}$ receptors, and is found predominantly in cells and tissues of the immune system (Klein, 2005; Mackie, 
2006). In the $\mathrm{CNS}, \mathrm{CB}_{2}$ receptor expression is associated with inflammation and it is primarily localized to microglia, resident macrophages of the CNS (Mackie, 2008; Palazuelos et al., 2009). This selective localization together with the modulatory effect of the $\mathrm{CB}_{2}$ receptor on microglia function is particularly relevant since microglial cells have a significant role in Alzheimer's disease (AD) and other diseases associated with the basal ganglia (Ramírez et al., 2005; Sagredo et al., 2007; Fernández-Ruiz et al., 2011; Yeh et al., 2016). Interestingly, recent work also indicates that $\mathrm{CB}_{2}$ receptors expressed in neurons can control synaptic function and are involved in drug abuse and synaptic plasticity (Xi et al., 2011; Stempel et al., 2016). For example, the selective $\mathrm{CB}_{2}$ receptor agonist JWH133 inhibits dopaminergic firing from the ventral tegmental area and reduced cocaine self-administration (Zhang et al., 2016). Furthermore, neuronal $\mathrm{CB}_{2}$ receptors work independently from $C_{1}$ receptors to modulate inhibitory plasticity in the CA2/3 regions of the hippocampus and gamma oscillations in vivo (Stempel et al., 2016). We predict more regulatory roles will be identified for the $\mathrm{CB}_{2}$ receptors expressed in neurons.

\section{ENDOCANNABINOIDS}

eCBs are produced on demand with their synthesis typically triggered via increased intracellular $\mathrm{Ca}^{2+}$ at postsynaptic sites in response to sustained synaptic activity (Figure 1A; Chevaleyre et al., 2006; Mackie, 2006; Heifets and Castillo, 2009). Major eCBs are rapidly deactivated by reuptake mechanisms and degrading enzymes, including fatty acid amide hydrolase (FAAH) and monoacylglycerol lipase (MAGL; Howlett et al., 2004; Mechoulam and Parker, 2013). Among eCBs, the derivatives of arachidonic acid such as AEA and 2-AG are dominant and orthosteric (Pertwee, 2015). These ligands are agonists for $C_{1}$ and $C_{2}$ receptors but bind $C_{1}$ receptors with higher affinity (AEA $\mathrm{Ki}=89 \mathrm{nM}$ and $321 \mathrm{nM}$ for $\mathrm{CB}_{1}$ and $\mathrm{CB}_{2}$ receptors respectively; 2-AG Ki $=472 \mathrm{nM}$ and $1400 \mathrm{nM}$ for $C_{1}$ and $C_{2}$ receptors respectively; Pertwee et al., 2010). More recently, allosteric eCBs have been identified, including pregnenolone and lipoxin $A 4$ which can modulate $\mathrm{CB}_{1}$ receptor signaling with possible therapeutic value (Pamplona et al., 2012; Vallée et al., 2014; Pertwee, 2015). Further pharmacological characterization is still needed of orthosteric and allosteric modulators to clearly elucidate their physiological roles and modes of action. Nevertheless, the pharmacological manipulation of eCB levels or their actions by allosteric modulators could provide alternative opportunities to regulate the ECS. For a comprehensive review on eCBs see Fonseca et al. (2013).

\section{THE ENDOCANNABINOID SYSTEM IN THE CNS}

The ECS has emerged as one of the key regulatory mechanisms in the brain controlling multiple events such as mood, pain perception, learning and memory among others (Marsicano and Lutz, 2006; Kano et al., 2009). It is also thought to provide a neuroprotective role during traumatic brain injury (TBI) and may be part of the brain's natural compensatory repair mechanism during neurodegeneration (Pryce et al., 2003; Klein, 2005; Campbell and Gowran, 2007; Bilkei-Gorzo, 2012). New roles for the ECS in drug abuse and dependence are identified almost continuously, further strengthening the relevance of this system not only during cannabis abuse but also other illicit drugs as well (Maldonado et al., 2006; Xi et al., 2011; Parsons and Hurd, 2015). In the CNS, eCBs act as retrograde messengers mediating feedback inhibition modulating synaptic plasticity (Howlett, 2005; Chevaleyre et al., 2006; Katona and Freund, 2012). Specifically, activation of the $\mathrm{CB}_{1}$ receptor leads to activation of inwardly rectifying $\mathrm{K}^{+}$channel conductance, decreases in N-type and P/Q-type voltage-operated $\mathrm{Ca}^{2+}$ channel conductance and $\mathrm{eCB}$ production (Figure 1A; Mackie et al., 1995; Twitchell et al., 1997; Guo and Ikeda, 2004; Demuth and Molleman, 2006). This results in a decrease of neurotransmitter release at excitatory and inhibitory synapses leading to transient effects, as in depolarizationinduced suppression of inhibition (DSI) and depolarizationinduced suppression of excitation (DSE) or persistent effects as in long-term depression and potentiation (LTP/LTD) during synaptic plasticity (Wilson and Nicoll, 2001; Chevaleyre et al., 2006; Heifets and Castillo, 2009; Kano et al., 2009; Castillo et al., 2012; Soltesz et al., 2015; Maroso et al., 2016). These events make the ECS a key modulator of synaptic plasticity.

Prolonged exposure to $\mathrm{CB}_{1}$ receptor agonists results in rapid attenuation of behavioral responsiveness, termed tolerance, in human and animal models that has been attributed to both a decrease in the ability of the receptor to activate effector pathways (i.e., desensitization) and in the reduction in the number of cell surface-expressed receptors (i.e., internalization; Howlett et al., 2004; Martini et al., 2007). At the molecular level, the agonist-bound GPCR becomes a substrate for G protein coupled receptor kinases (GRKs); these kinases phosphorylate serine and/or threonine residues on GPCR cytoplasmic domains, which then become a high affinity target for $\beta$-arrestins (Jin et al., 1999; Delgado-Peraza et al., 2016). Binding of $\beta$-arrestins uncouples G-proteins and stimulates receptor internalization and $\beta$-arrestin mediated signaling (Jin et al., 1999; Roche et al., 1999).

Ligand induced receptor phosphorylation by GRKs can result in very specific and distinct phosphorylation profiles or "barcodes" (Butcher et al., 2011; Liggett, 2011; Delgado-Peraza et al., 2016). These bar-codes are finely tuned and define which signaling cascades are activated, thus opening up a spectrum of possibilities frequently defined as functional selectivity or ligand bias (Liggett, 2011; Nobles et al., 2011; Prihandoko et al., 2016). However, careful consideration must be taken when interpreting results obtained from heterologous systems, particularly when signaling can be significantly affected (biased) by the different levels of protein expression across different cell types (Bosier et al., 2010; Atwood et al., 2011; Straiker et al., 2012).

Supporting the bar-code hypothesis and identifying the mechanisms and signaling cascades downstream from the $\mathrm{CB}_{1}$ receptor/ $\beta$-arrestins, our recent data indicates that receptor and $\beta$-arrestin interaction and signaling cascades are dependent 
on specific phosphorylation sites controlled by unique GRKs (Delgado-Peraza et al., 2016). Mutation of the putative GRK sites from S426/S430 to alanines (rat sequence conserved in human) resulted in reduced $\beta$-arrestin 2 recruitment and receptor internalization, but enhanced interaction with $\beta$-arrestin 1 and increased $\beta$-arrestin 1 mediated signaling (Ahn et al., 2013; Delgado-Peraza et al., 2016). Replacement of series $426 / 430$ to alanines renders the $\mathrm{CB}_{1}$ receptors biased towards $\beta$-arrestin 1 signaling and provides an ideal tool to probe the signaling pathways, mechanisms and roles of these cascades. $\beta$-arrestin mediated signaling from this biased receptor controls the activation of several cascades including ERK1/2, JNK1/2/3, CREB and P38 $\alpha$. It is important to note that these cascades have been previously linked to the activation of $\mathrm{CB}_{1}$ receptors, but not all to $\beta$-arrestins (Rueda et al., 2000; Derkinderen et al., 2001; Hart et al., 2004). Activation of these cascades by $\mathrm{CB}_{1}$ receptors and $\beta$-arrestins resulted in the regulation of gene expression and protein synthesis (Delgado-Peraza et al., 2016).

Elucidating the physiological roles of $\beta$-arrestins may foster the development of pathway-selective or "biased ligands" with greater therapeutic benefit. Investigating signaling from biased $\mathrm{CB}_{1}$ receptors such as S426A/S430A and the DRY mutant (AspArg-Tyr) together with the identification of biased ligands and the crystal structure of $\mathrm{CB}_{1}$ receptors should provide important tools to elucidate the mechanisms and roles of $\mathrm{CB}_{1}$ receptor signaling (Gyombolai et al., 2015; Delgado-Peraza et al., 2016; Hua et al., 2016).

The subcellular localization and trafficking of $\mathrm{CB}_{1}$ receptors is highly dynamic, with significant effects on receptor signaling (Leterrier et al., 2004; Brailoiu et al., 2011; Rozenfeld, 2011; Dudok et al., 2015). $\mathrm{CB}_{1}-\mathrm{G}$ protein mediated signaling occurs at the cell surface and at intracellular compartments (Rozenfeld and Devi, 2008; Brailoiu et al., 2014). At the cell surface, $\mathrm{CB}_{1}$ receptor ligands modulate the interaction between receptors and $\beta$-arrestin as a mechanism to influence $\beta$-arrestin mediated signaling (Flores-Otero et al., 2014). This interaction is initiated at the plasma membrane and can continue into intracellular compartments (Delgado-Peraza et al., 2016). Interestingly, these location-specific signaling events appear to be widespread among several GPCRs. For example, the LH receptor, $\beta 2$ adrenergic receptor and the $\mathrm{CB}_{2}$ receptor can signal from intracellular compartments either by $\beta$-arrestins or $\mathrm{G}$ proteins via a "supercomplex" ultimately resulting in three different spatio-temporal signaling waves (Brailoiu et al., 2014; Irannejad and von Zastrow, 2014; Lyga et al., 2016; Nogueras-Ortiz and Yudowski, 2016; Thomsen et al., 2016). Constitutive activation also plays a role in their trafficking (Leterrier et al., 2006; McDonald et al., 2007). $\mathrm{CB}_{1}$ receptor location and trafficking are highly dynamic events that are intimately intertwined with their signaling (Dudok et al., 2015). What is the role and relevance of this compartment selective signaling event? Considering the restrictive location of $\mathrm{CB}_{1}$ receptors to presynaptic sites, a possible role could be the local modulation of gene and protein expression after chronic receptor activation. Where do these intracellularly active receptors go and when do they stop signaling are intriguing questions that should provide clues to their physiological roles.

\section{$\Delta^{9}$-THC}

The cannabis plant contains more than 60 different active synthetic ligands for $\mathrm{CB} 1 / 2$ (CBs) with $\Delta^{9}$-THC being the major psychoactive molecule among them (Brenneisen, 2007). Exposure to $\Delta^{9}$-THC leads to pleiotropic and sometimes paradoxical effects in humans including analgesic responses, relaxation, dysphoria, tolerance and dependence (Mechoulam and Parker, 2013). Most of these effects are blocked with SR141716, a selective blocker of $\mathrm{CB}_{1}$ receptors (Huestis et al., 2001). In rodents, repetitive administration of $\Delta^{9}$-THC results not only in tolerance but characteristically in a "tetrad" response which includes antinociception, hypothermia, hypoactivity and catalepsy (Little et al., 1988; Fride et al., 2006; Nguyen et al., 2012). However, lack of behavioral sensitization has also been described in mice chronically exposed to $\Delta^{9}$-THC (Varvel et al., 2007). At the molecular level, $\Delta^{9}$-THC acts as a partial agonist of the $C_{1}$ receptor, at the $G$ protein level and as a potent activator of $\beta$-arrestin 2 recruitment and signaling in heterologous systems (Pertwee et al., 2010; Laprairie et al., 2014, 2016). Perhaps the complex behavioral responses to $\Delta^{9}$-THC could be mediated by the selective activation of these different signaling cascades. Interestingly, $\beta$-arrestins mediate some of the behaviors associated with long-term exposure to $\Delta^{9}$-THC (Breivogel et al., 2008; Wu et al., 2008). $\beta$-arrestin $2 \mathrm{KO}$ mice display enhanced antinociceptive response to acute $\Delta^{9}$-THC and a decrease in tolerance, indicating the relevance of classical roles of $\beta$-arrestin (i.e., receptor desensitization) during $G$ protein signaling (Nguyen et al., 2012). However, recent work on $\beta$-arrestin $1 \mathrm{KO}$ mice indicates divergent roles of $\beta$-arrestin $1 / 2$ and proposed that $\beta$-arrestin 1 regulates receptor sensitivity in an agonist dependent manner, with no significant effects regulating $\mathrm{CB}$ tolerance (Breivogel and Vaghela, 2015). Interestingly, our work and others also suggest $\beta$-arrestin 1 as the "signaling" arrestin for $\mathrm{CB}_{1}$ receptor. This divergence could be exploited to design compounds that are biased towards $G$ protein signaling with less receptor desensitization and decreased tolerance as recently demonstrated for pain modulation with the mu opioid receptor (Manglik et al., 2016).

\section{$\mathrm{CB}_{1}$ RECEPTORS IN DISEASE}

$\mathrm{CB}_{1}$ receptors are indicated in many disorders that impact the CNS including several neurodegenerative disorders such as Huntington's disease (HD), multiple sclerosis (MS) and AD (Fernández-Ruiz et al., 2011; Di Marzo et al., 2014).

\section{MULTIPLE SCLEROSIS}

MS is a major immune-related neurodegenerative disease characterized by demyelinization with axonal and neuronal loss. Several clinical trials present positive effects of either cannabis, $\Delta^{9}$-THC or other CB agonist on spasticity, spasms and pain among other signs of MS (Croxford, 2003; Pertwee, 2007; Rog, 2010; Notcutt et al., 2012). Use of Sativex ${ }^{\circledR}$ (Nabiximol) an oromucosal spray of cannabis extract containing fixed 
concentrations of $\Delta^{9}$-THC and cannabidiol (CBD), results in symptomatic improvement in patients with MS. There is a reduction in motor dysfunction and pain, observed in meta-analysis of several clinical studies. However, an increased incidence of non-serious side effects was also reported (Wade et al., 2010; Otero-Romero et al., 2016). Importantly, a review by the National Institute for Health and Care Excellence in the United Kingdom, recommended against the use of Sativex ${ }^{\circledR}$ to treat spasticity in people with MS because it is not a cost effective treatment (Multiple sclerosis in adults: management | 1-recommendations | Guidance and guidelines | NICE, 2014). For a recent and comprehensive analysis of clinical studies see the work of Otero-Romero et al. (2016).

At the molecular level, these improvements are generally linked to the activation of both $\mathrm{CB}_{1}$ receptors and $\mathrm{CB}_{2}$ receptors by agonist, resulting in their dual anti-inflammatory and neuroprotective effects throughout the CNS (Baker et al., 2000; Maresz et al., 2007). These effects include up-regulation of prosurvival molecules such as interleukines in astroglia, and the reduction of cytotoxic factors such as nitric oxide, reactive oxygen species and proinflammatory cytokines in microglia (Fernández-Ruiz et al., 2011). The precise mechanisms by which receptors exert their neuroprotective activity might include activation of phosphatidylinositol 3-kinase/mammalian target of rapamycin complex 1 (mTOR1) pathway and brain-derived neurotrophic factor (BDNF; Ozaita et al., 2007; Blázquez et al., 2015).

Consistent with the clinical data, using synthetic CBs lead to a reduction in inflammation and neuropathic pain in the Experimental Autoimmune Encephalomyelitis (EAE) mouse model (Pryce et al., 2003; Maresz et al., 2007; Fu and Taylor, 2015). Similar results were observed with systemic treatment with the agonists, WIN55212-2, ACEA and JWH-015 of mice with established Theiler's Murine Encephalomyelitis Virus-induced Demyelinating Disease, a mouse model of chronic progressive MS. Mouse motor function was improved by modulating microglia and lymphocyte infiltration into the spinal cord (Arévalo-Martín et al., 2003). In contrast, when an inverse agonist of the $\mathrm{CB}_{1}$ receptor (SR141716A) was applied, the EAE was worsened likely by releasing pro-inflammatory cytokines in the mouse brain and spinal cord (Saito et al., 2012). Underlying the role of $\mathrm{CB}_{1}$ receptors during neuromodulation and inflammation, work on $\mathrm{CB}_{1}$ receptor $^{-/-}$mice suggest that these animals are more susceptible to neurotoxicity and damage when compared to wild-type mice (Jackson et al., 2005; Pertwee, 2007). Taken together these results suggest that in MS, the neuroprotective roles of $\mathrm{CB}_{1}$ and $\mathrm{CB}_{2}$ receptors might be impaired and their enhancement could provide new therapeutic approaches. For a comprehensive review of the literature of MS from model systems to clinical studies see Pertwee (2007) and $\operatorname{Rog}(2010)$.

\section{HUNTINGTON's DISEASE}

Dysregulation of the ECS is also reported in experimental models and patients with $\mathrm{HD}$. The $\mathrm{CB}_{1}$ receptor expression is reduced, at least somewhat (e.g., $27 \%$ decrease in the striatum of the $\mathrm{CB}_{1}$ receptor mRNA), prior to symptoms of neurodegenerative HD in mice (McCaw et al., 2004). Losing the $\mathrm{CB}_{1}$ receptor expression decreases motor performance and increases the amount of aggregates in the striatum of $\mathrm{HD}$ mice (Mievis et al., 2011). Major loss of $\mathrm{CB}_{1}$ receptors is also reported in patients with $\mathrm{HD}$ (Glass et al., 2000). Interestingly, activation of the $\mathrm{CB}_{1}$ receptor may help reduce the progression of HD. For example, preclinical evidence suggested the use of CBs such as Sativex ${ }^{\circledR}$ for neuroprotection in patients with progressive neurodegenerative conditions like HD (Valdeolivas et al., 2012). Furthermore, selected receptor agonists have neuroprotective potential in a cell culture model of HD (Scotter et al., 2010; Laprairie et al., 2016). Interestingly, ligands biased to $\beta$-arrestin mediated signaling such as $\Delta^{9}$-THC, reduced cellular function and viability in these models, suggesting a potential pharmacological profile for therapeutic agonists (Laprairie et al., 2014, 2016). These events are mediated in part by the activation of $\mathrm{G} \alpha_{\mathrm{i} / \mathrm{o}}$ mediated pathways and might limit glutamate release from cortical neurons and GABA from striatal medium spiny neurons (Dowie et al., 2010; Laprairie et al., 2016). Results obtained investigating the R6/2 mouse model of $\mathrm{HD}$, indicate that $\mathrm{CB}_{1}$ receptor activation parallels $B D N F$ expression leading to neuroprotection (Blázquez et al., 2015). In general, the in vivo and in vitro data suggest that $C B$ agonist with specific pharmacological profiles (biased towards $B D N F$ upregulation and release) could be developed to treat or ameliorate HD.

\section{ALZHEIMER'S DISEASE}

$\mathrm{CB}_{1}$ receptors have also been the focus of intense research as a potential target in AD. This work has been performed in vitro, animal models and post-mortem samples. Changes in the expression levels of several components of the ECS in postmortem samples from $\mathrm{AD}$ patients have been identified, although their role in the pathophysiology of the disorder is still unknown. For example, $\mathrm{CB}_{1}$ receptors in hippocampus from patients with $\mathrm{AD}$ were not different from aged-matched controls. However, the levels of MAGLs, the degradative enzyme of 2-AG, were reduced at their site of action in these patients, suggesting an altered eCB signaling and architecture (Mulder et al., 2011). Limited positive behavioral results have been observed in small clinical trials and pilot studies using analogs of $\Delta^{9}$-THC (Aso and Ferrer, 2014). Analysis of the studies and trials available, suggest significant benefits from synthetic CBs on some of the behavioral and psychological symptoms of dementia (Liu et al., 2015). However, these conclusions were based on short and limited studies; further work will be needed to assess the safety and efficacy of $\mathrm{CBs}$ in $\mathrm{AD}$. In experimental models of $\mathrm{AD}$, several findings indicate that the activation of both $\mathrm{CB}_{1}$ receptors and $\mathrm{CB}_{2}$ receptors might have beneficial effects mainly through neuroprotection against $A \beta$ toxicity as previously noted for other neurodegenerative disorders. For example, by crossbreeding the $\mathrm{AD}$ mouse model (APP23) with the $\mathrm{CB}_{1}$ receptor-deficient mouse, enhanced cognitive impairment was observed while presenting a reduced amyloid deposition (Stumm et al., 2013). Tau protein phosphorylation is also reduced by CBD 
in PC12 cells, providing a different neuroprotective mechanism during $\mathrm{AD}$ (Esposito et al., 2006). Since $\mathrm{CB}_{1}$ receptors are not likely directly activated by $\mathrm{CBD}$, the impact on Tau phosphorylation may be via the antioxidant effect of $\mathrm{CBD}$ or perhaps as a $\mathrm{CB}$ receptor independent effect. A reduction in harmful $\beta$-amyloid peptide and tau phosphorylation, while promoting intrinsic CNS repair mechanisms may take place consecutively due to activation of the immune and CNS $\mathrm{CB}$ system in AD (Aso and Ferrer, 2014). For example, recent work on the TREM2 receptor in microglia, where $\mathrm{CB}_{2}$ receptors are expressed and control cellular responses, also provides an immune related mechanism to control $\mathrm{AD}$ (Yeh et al., 2016).

Aging is a major risk factor for neurodegenerative diseases and neuronal progenitor cell proliferation is greatly reduced in the process. Remarkably, CBs can stimulate embryonic and adult neurogenesis (Jiang et al., 2005; Trazzi et al., 2010). Axonal guidance, cell migration, synapse formation and cell survival are also modulated during development. Dysregulation of these processes during development and aging could significantly contribute to multiple disorders of the CNS. For an extensive and thorough review of this topic see the work of Di Marzo et al. (2014) and Maccarrone et al. (2014).

\section{TRAUMATIC BRAIN INJURY}

There is good agreement that the $\mathrm{CB}_{1 / 2}$ receptors are involved in TBI and that 2-AG increases after TBI in animal models (Panikashvili et al., 2001; Mechoulam and Shohami, 2007). There is an "on-demand" signal to generate eCB following TBI that can decrease brain edema and inflammation (Shohami et al., 2011; Gruenbaum et al., 2016). These events may be neuroprotective and prevent excitotoxicity, inhibit inflammatory cytokine production and augment stem cell migration and differentiation. Furthermore, $\mathrm{CB}_{1}$ receptor and $\mathrm{CB}_{2}$ receptor antagonists prevent drug-induced neuroprotection in a mouse mode of TBl (Lopez-Rodriguez et al., 2015). However, as indicated previously for other

\section{REFERENCES}

Ahn, K. H., Mahmoud, M. M., Shim, J.-Y., and Kendall, D. A. (2013). Distinct roles of $\beta$-arrestin 1 and $\beta$-arrestin 2 in ORG27569-induced biased signaling and internalization of the cannabinoid receptor $1\left(\mathrm{CB}_{1}\right)$. J. Biol. Chem. 288, 9790-9800. doi: 10.1074/jbc.M112.438804

Arévalo-Martín, A., Vela, J. M., Molina-Holgado, E., Borrell, J., and Guaza, C. (2003). Therapeutic action of cannabinoids in a murine model of multiple sclerosis. J. Neurosci. 23, 2511-2516.

Aso, E., and Ferrer, I. (2014). Cannabinoids for treatment of Alzheimer's disease: moving toward the clinic. Front. Pharmacol. 5:37. doi: 10.3389/fphar.2014. 00037

Atwood, B. K., Lopez, J., Wager-Miller, J., Mackie, K., and Straiker, A. (2011). Expression of G protein-coupled receptors and related proteins in HEK293, AtT20, BV2 and N18 cell lines as revealed by microarray analysis. BMC Genomics 12:14. doi: 10.1186/1471-2164-12-14

Baker, D., Pryce, G., Croxford, J. L., Brown, P., Pertwee, R. G., Huffman, J. W., et al. (2000). Cannabinoids control spasticity and tremor in a multiple sclerosis model. Nature 404, 84-87. doi: 10.1038/350 03583 disorders, limited clinical data is available to support efficacy and safety of CBs during TBI (Gruenbaum et al., 2016).

\section{FUTURE STUDIES}

The modulation of the ECS has great therapeutic potential in many neuropsychiatric and neurodegenerative disorders. Our understanding of the in vivo and in vitro pharmacology of the $C_{1}$ receptors and $C_{2}$ receptors has significantly increased over the last decades, with new insights into the pathways controlled and the roles of these receptors, enzymes and ligands emerging regularly in the literature. However, this knowledge has not made a complete transition into drug development yet. Complicating this progression, is the mounting anecdotal evidence obtained from cannabis use, which contains over $60 \mathrm{CBs}$ plus other relevant compounds at different concentrations. This variability, together with limited information from clinical trials makes it difficult to scientifically assess the multiple claims associated with cannabis use. Careful investigation of defined molecular entities, in randomized double blind, placebo controlled and multicentric studies should be implemented to clearly move the field forward. At the same time, further work should be performed utilizing cellular and animal models to clearly identify the desired mechanisms and signaling pathways to be therapeutically targeted.

\section{AUTHOR CONTRIBUTIONS}

DAK and GAY wrote and revised this article.

\section{ACKNOWLEDGMENTS}

We offer our apologies to all authors whose work was not included in this review. The authors thank Yu-Hsien Liao who contributed to Figure 1. This work was supported by a grant from The National Institutes of Health to DAK and GAY (DA040920) and (DA037924) to GAY.

Bilkei-Gorzo, A. (2012). The endocannabinoid system in normal and pathological brain ageing. Philos. Trans. R. Soc. Lond. B Biol. Sci. 367, 3326-3341. doi: 10. 1098/rstb.2011.0388

Blázquez, C., Chiarlone, A., Bellocchio, L., Resel, E., Pruunsild, P., GarcíaRincón, D., et al. (2015). The $\mathrm{CB}_{1}$ cannabinoid receptor signals striatal neuroprotection via a PI3K/Akt/mTORC1/BDNF pathway. Cell Death Differ. 22, 1618-1629. doi: 10.1038/cdd.2015.11

Bosier, B., Muccioli, G. G., Hermans, E., and Lambert, D. M. (2010). Functionally selective cannabinoid receptor signalling: therapeutic implications and opportunities. Biochem. Pharmacol. 80, 1-12. doi: 10.1016/j.bcp.2010.02.013

Bouaboula, M., Perrachon, S., Milligan, L., Canat, X., Rinaldi-Carmona, M., Portier, M., et al. (1997). A selective inverse agonist for central cannabinoid receptor inhibits mitogen-activated protein kinase activation stimulated by insulin or insulin-like growth factor 1: evidence for a new model of receptor/ligand interactions. J. Biol. Chem. 272, 22330-22339. doi: 10.1074/jbc. 272.35.22330

Brailoiu, G. C., Deliu, E., Marcu, J., Hoffman, N. E., Console-Bram, L., Zhao, P., et al. (2014). Differential activation of intracellular versus plasmalemmal CB2 cannabinoid receptors. Biochemistry 53, 4990-4999. doi: 10.1021/bi500632a 
Brailoiu, G. C., Oprea, T. I., Zhao, P., Abood, M. E., and Brailoiu, E. (2011). Intracellular cannabinoid type $1\left(\mathrm{CB}_{1}\right)$ receptors are activated by anandamide. J. Biol. Chem. 286, 29166-29174. doi: 10.1074/jbc.M110.217463

Breivogel, C. S., Lambert, J. M., Gerfin, S., Huffman, J. W., and Razdan, R. K. (2008). Sensitivity to $\Delta 9$-tetrahydrocannabinol is selectively enhanced in beta-arrestin2-/- mice. Behav. Pharmacol. 19, 298-307. doi: 10.1097/FBP. 0b013e328308f1e6

Breivogel, C. S., and Vaghela, M. S. (2015). The effects of beta-arrestin1 deletion on acute cannabinoid activity, brain cannabinoid receptors and tolerance to cannabinoids in mice. J. Recept. Signal Transduct. Res. 35, 98-106. doi: 10. 3109/10799893.2014.1003659

Brenneisen, R. (2007). "Chemistry and analysis of phytocannabinoids and other cannabis constituents," in Forensic Science And Medicine, ed. M. A. ElSohly (Totowa, NJ: Humana Press), 17-49.

Butcher, A. J., Prihandoko, R., Kong, K. C., McWilliams, P., Edwards, J. M., Bottrill, A., et al. (2011). Differential G-protein-coupled receptor phosphorylation provides evidence for a signaling bar code. J. Biol. Chem. 286, 11506-11518. doi: 10.1074/jbc.M110.154526

Campbell, V. A., and Gowran, A. (2007). Alzheimer's disease; taking the edge off with cannabinoids? Br. J. Pharmacol. 152, 655-662. doi: 10.1038/sj.bjp.0707446

Castillo, P. E., Younts, T. J., Chávez, A. E., and Hashimotodani, Y. (2012). Endocannabinoid signaling and synaptic function. Neuron 76, 70-81. doi: 10. 1016/j.neuron.2012.09.020

Chevaleyre, V., Takahashi, K. A., and Castillo, P. E. (2006). Endocannabinoidmediated synaptic plasticity in the CNS. Annu. Rev. Neurosci. 29, 37-76. doi: 10. 1146/annurev.neuro.29.051605.112834

Croxford, J. L. (2003). Therapeutic potential of cannabinoids in CNS disease. CNS Drugs 17, 179-202. doi: 10.2165/00023210-200317030-00004

Delgado-Peraza, F., Ahn, K. H., Nogueras-Ortiz, C., Mungrue, I. N., Mackie, K., Kendall, D. A., et al. (2016). Mechanisms of biased $\beta$-arrestin-mediated signaling downstream from the cannabinoid 1 receptor. Mol. Pharmacol. 89, 618-629. doi: 10.1124/mol.115.103176

Demuth, D. G., and Molleman, A. (2006). Cannabinoid signalling. Life Sci. 78, 549-563. doi: 10.1016/j.lfs.2005.05.055

Derkinderen, P., Ledent, C., Parmentier, M., and Girault, J. A. (2001). Cannabinoids activate p38 mitogen-activated protein kinases through $\mathrm{CB}_{1}$ receptors in hippocampus. J. Neurochem. 77, 957-960. doi: 10.1046/j.14714159.2001.00333.x

Dowie, M. J., Howard, M. L., Nicholson, L. F. B., Faull, R. L. M., Hannan, A. J., and Glass, M. (2010). Behavioural and molecular consequences of chronic cannabinoid treatment in Huntington's disease transgenic mice. Neuroscience 170, 324-336. doi: 10.1016/j.neuroscience.2010.06.056

Dudok, B., Barna, L., Ledri, M., Szabó, S. I., Szabadits, E., Pintér, B., et al. (2015). Cell-specific STORM super-resolution imaging reveals nanoscale organization of cannabinoid signaling. Nat. Neurosci. 18, 75-86. doi: 10.1038/ nn. 3892

Eldeeb, K., Leone-Kabler, S., and Howlett, A. C. (2016). CB CB $_{1}$ cannabinoid receptor-mediated increases in cyclic AMP accumulation are correlated with reduced Gi/o function. J. Basic Clin. Physiol. Pharmacol. 27, 311-322. doi: 10. 1515/jbcpp-2015-0096

Esposito, G., De Filippis, D., Carnuccio, R., Izzo, A. A., and Iuvone, T. (2006). The marijuana component cannabidiol inhibits $\beta$-amyloid-induced tau protein hyperphosphorylation through Wnt/ $\beta$-catenin pathway rescue in PC12 cells. J. Mol. Med. (Berl) 84, 253-258. doi: 10.1007/s00109-005-0025-1

Fernández-Ruiz, J., Moreno-Martet, M., Rodríguez-Cueto, C., Palomo-Garo, C., Gómez-Cañas, M., Valdeolivas, S., et al. (2011). Prospects for cannabinoid therapies in basal ganglia disorders. Br. J. Pharmacol. 163, 1365-1378. doi: 10. 1111/j.1476-5381.2011.01365.x

Flores-Otero, J., Ahn, K. H., Delgado-Peraza, F., Mackie, K., Kendall, D. A., and Yudowski, G. A. (2014). Ligand-specific endocytic dwell times control functional selectivity of the cannabinoid receptor 1. Nat. Commun. 5:4589. doi: 10.1038/ncomms5589

Fonseca, B. M., Costa, M. A., Almada, M., Correia-da-Silva, G., and Teixeira, N. A. (2013). Endogenous cannabinoids revisited: a biochemistry perspective. Prostaglandins Other Lipid Mediat. 102-103, 13-30. doi: 10.1016/j. prostaglandins.2013.02.002

Fride, E., Perchuk, A., Hall, F. S., Uhl, G. R., and Onaivi, E. S. (2006). Behavioral methods in cannabinoid research. Methods Mol. Med. 123, 269-290. doi: 10. 1385/1-59259-999-0:269
Fu, W., and Taylor, B. K. (2015). Activation of cannabinoid CB2 receptors reduces hyperalgesia in an experimental autoimmune encephalomyelitis mouse model of multiple sclerosis. Neurosci. Lett. 595, 1-6. doi: 10.1016/j.neulet.2015.04.002

Glass, M., Dragunow, M., and Faull, R. L. M. (2000). The pattern of neurodegeneration in Huntington's disease: a comparative study of cannabinoid, dopamine, adenosine and $\mathrm{GABA}_{\mathrm{A}}$ receptor alterations in the human basal ganglia in Huntington's disease. Neuroscience 97, 505-519. doi: 10.1016/s0306-4522(00)00008-7

Glass, M., and Felder, C. C. (1997). Concurrent stimulation of cannabinoid $\mathrm{CB}_{1}$ and dopamine D2 receptors augments cAMP accumulation in striatal neurons: evidence for a Gs linkage to the $\mathrm{CB}_{1}$ receptor. J. Neurosci. 17, 5327-5333.

Glass, M., and Northup, J. K. (1999). Agonist selective regulation of G proteins by cannabinoid $\mathrm{CB}_{1}$ and $\mathrm{CB}_{2}$ receptors. Mol. Pharmacol. 56, 1362-1369.

Gruenbaum, S. E., Zlotnik, A., Gruenbaum, B. F., Hersey, D., and Bilotta, F. (2016). Pharmacologic neuroprotection for functional outcomes after traumatic brain injury: a systematic review of the clinical literature. CNS Drugs 30, 791-806. doi: 10.1007/s40263-016-0355-2

Guo, J., and Ikeda, S. R. (2004). Endocannabinoids modulate N-type calcium channels and G-protein-coupled inwardly rectifying potassium channels via $\mathrm{CB}_{1}$ cannabinoid receptors heterologously expressed in mammalian neurons. Mol. Pharmacol. 65, 665-674. doi: 10.1124/mol.65.3.665

Gyombolai, P., Tóth, A. D., Timár, D., Turu, G., and Hunyady, L. (2015). Mutations in the "DRY" motif of the $\mathrm{CB}_{1}$ cannabinoid receptor result in biased receptor variants. J. Mol. Endocrinol. 54, 75-89. doi: 10.1530/JME-140219

Hart, S., Fischer, O. M., and Ullrich, A. (2004). Cannabinoids induce cancer cell proliferation via tumor necrosis factor $\alpha$-converting enzyme (TACE/ADAM17)-mediated transactivation of the epidermal growth factor receptor. Cancer Res. 64, 1943-1950. doi: 10.1158/0008-5472.can03-3720

Heifets, B. D., and Castillo, P. E. (2009). Endocannabinoid signaling and long-term synaptic plasticity. Annu. Rev. Physiol. 71, 283-306. doi: 10.1146/annurev. physiol.010908.163149

Herkenham, M., Lynn, A. B., Johnson, M. R., Melvin, L. S., de Costa, B. R., and Rice, K. C. (1991). Characterization and localization of cannabinoid receptors in rat brain: a quantitative in vitro autoradiographic study. J. Neurosci. 11, $563-583$.

Howlett, A. C. (2005). Cannabinoid receptor signaling. Handb. Exp. Pharmacol. 168, 53-79. doi: 10.1007/3-540-26573-2_2

Howlett, A. C., Barth, F., Bonner, T. I., Cabral, G., Casellas, P., Devane, W. A., et al. (2002). International union of pharmacology. XXVII. Classification of cannabinoid receptors. Pharmacol. Rev. 54, 161-202. doi: 10.1124/pr. 54.2 .161

Howlett, A. C., Breivogel, C. S., Childers, S. R., Deadwyler, S. A., Hampson, R. E., and Porrino, L. J. (2004). Cannabinoid physiology and pharmacology: 30 years of progress. Neuropharmacology 47, 345-358. doi: 10.1016/j.neuropharm.2004. 07.030

Hua, T., Vemuri, K., Pu, M., Qu, L., Won Han, G., Wu, Y., et al. (2016). Crystal structure of the human cannabinoid receptor $\mathrm{CB}_{1}$. Cell 167, 750.e14-762.e14. doi: 10.1016/j.cell.2016.10.004

Huestis, M. A., Gorelick, D. A., Heishman, S. J., Preston, K. L., Nelson, R. A., Moolchan, E. T., et al. (2001). Blockade of effects of smoked marijuana by the $\mathrm{CB}_{1}$-selective cannabinoid receptor antagonist SR141716. Arch. Gen. Psychiatry 58, 322-328. doi: 10.1001/archpsyc.58.4.322

Irannejad, R., and von Zastrow, M. (2014). GPCR signaling along the endocytic pathway. Curr. Opin. Cell Biol. 27, 109-116. doi: 10.1016/j.ceb.2013. 10.003

Jackson, S. J., Pryce, G., Diemel, L. T., Cuzner, M. L., and Baker, D. (2005). Cannabinoid-receptor 1 null mice are susceptible to neurofilament damage and caspase 3 activation. Neuroscience 134, 261-268. doi: 10.1016/j.neuroscience. 2005.02.045

Jiang, W., Zhang, Y., Xiao, L., Van Cleemput, J., Ji, S. P., Bai, G., et al. (2005). Cannabinoids promote embryonic and adult hippocampus neurogenesis and produce anxiolytic- and antidepressant-like effects. J. Clin. Invest. 115, 3104-3116. doi: 10.1172/jci25509

Jin, W., Brown, S., Roche, J. P., Hsieh, C., Celver, J. P., Kovoor, A., et al. (1999). Distinct domains of the $\mathrm{CB}_{1}$ cannabinoid receptor mediate desensitization and internalization. J. Neurosci. 19, 3773-3780. 
Kano, M., Ohno-Shosaku, T., Hashimotodani, Y., Uchigashima, M., and Watanabe, M. (2009). Endocannabinoid-mediated control of synaptic transmission. Physiol. Rev. 89, 309-380. doi: 10.1152/physrev.000 19.2008

Katona, I., and Freund, T. F. (2012). Multiple functions of endocannabinoid signaling in the brain. Annu. Rev. Neurosci. 35, 529-558. doi: 10.1146/annurevneuro-062111-150420

Kenakin, T. (2004). Principles: receptor theory in pharmacology. Trends Pharmacol. Sci. 25, 186-192. doi: 10.1016/j.tips.2004.02.012

Klein, T. W. (2005). Cannabinoid-based drugs as anti-inflammatory therapeutics. Nat. Rev. Immunol. 5, 400-411. doi: 10.1038/nri1602

Laprairie, R. B., Bagher, A. M., Kelly, M. E. M., and Denovan-Wright, E. M. (2016). Biased type 1 cannabinoid receptor signaling influences neuronal viability in a cell culture model of Huntington disease. Mol. Pharmacol. 89, 364-375. doi: 10. 1124/mol.115.101980

Laprairie, R. B., Bagher, A. M., Kelly, M. E. M., Dupré, D. J., and Denovan-Wright, E. M. (2014). Type 1 cannabinoid receptor ligands display functional selectivity in a cell culture model of striatal medium spiny projection neurons. J. Biol. Chem. 289, 24845-24862. doi: 10.1074/jbc.m114. 557025

Leterrier, C., Bonnard, D., Carrel, D., Rossier, J., and Lenkei, Z. (2004). Constitutive endocytic cycle of the $\mathrm{CB}_{1}$ cannabinoid receptor. J. Biol. Chem. 279, 36013-36021. doi: 10.1074/jbc.M403990200

Leterrier, C., Lainé, J., Darmon, M., Boudin, H., Rossier, J., and Lenkei, Z. (2006). Constitutive activation drives compartment-selective endocytosis and axonal targeting of type 1 cannabinoid receptors. J. Neurosci. 26, 3141-3153. doi: 10. 1523/JNEUROSCI.5437-05.2006

Liggett, S. B. (2011). Phosphorylation barcoding as a mechanism of directing GPCR signaling. Sci. Signal. 4:pe36. doi: 10.1126/scisignal.20 02331

Little, P. J., Compton, D. R., Johnson, M. R., Melvin, L. S., and Martin, B. R. (1988). Pharmacology and stereoselectivity of structurally novel cannabinoids in mice. J. Pharmacol. Exp. Ther. 247, 1046-1051.

Liu, C. S., Chau, S. A., Ruthirakuhan, M., Lanctôt, K. L., and Herrmann, N. (2015). Cannabinoids for the treatment of agitation and aggression in Alzheimer's disease. CNS Drugs 29, 615-623. doi: 10.1007/s40263-015-0270-y

Lopez-Rodriguez, A. B., Siopi, E., Finn, D. P., Marchand-Leroux, C., GarciaSegura, L. M., Jafarian-Tehrani, M., et al. (2015). $\mathrm{CB}_{1}$ and $\mathrm{CB}_{2}$ cannabinoid receptor antagonists prevent minocycline-induced neuroprotection following traumatic brain injury in mice. Cereb. Cortex 25, 35-45. doi: 10.1093/cercor/ bht202

Lyga, S., Volpe, S., Werthmann, R. C., Götz, K., Sungkaworn, T., Lohse, M. J., et al. (2016). Persistent cAMP signaling by internalized LH receptors in ovarian follicles. Endocrinology 157, 1613-1621. doi: 10.1210/en.2015-1945

Maccarrone, M., Guzmán, M., Mackie, K., Doherty, P., and Harkany, T. (2014). Programming of neural cells by (endo)cannabinoids: from physiological rules to emerging therapies. Nat. Rev. Neurosci. 15, 786-801. doi: 10.1038/ nrn3846

Mackie, K. (2006). Mechanisms of $\mathrm{CB}_{1}$ receptor signaling: endocannabinoid modulation of synaptic strength. Int. J. Obes. (Lond). 30, S19-S23. doi: 10. 1038/sj.ijo.0803273

Mackie, K. (2008). Cannabinoid receptors: where they are and what they do. J. Neuroendocrinol. 20, 10-14. doi: 10.1111/j.1365-2826.2008. 01671.x

Mackie, K., Lai, Y., Westenbroek, R., and Mitchell, R. (1995). Cannabinoids activate an inwardly rectifying potassium conductance and inhibit Q-type calcium currents in AtT20 cells transfected with rat brain cannabinoid receptor. J. Neurosci. 15, 6552-6561.

Maldonado, R., Valverde, O., and Berrendero, F. (2006). Involvement of the endocannabinoid system in drug addiction. Trends Neurosci. 29, 225-232. doi: 10.1016/j.tins.2006.01.008

Manglik, A., Lin, H., Aryal, D. K., McCorvy, J. D., Dengler, D., Corder, G., et al. (2016). Structure-based discovery of opioid analgesics with reduced side effects. Nature 537, 185-190. doi: 10.1038/nature19112

Maresz, K., Pryce, G., Ponomarev, E. D., Marsicano, G., Croxford, J. L., Shriver, L. P., et al. (2007). Direct suppression of CNS autoimmune inflammation via the cannabinoid receptor $\mathrm{CB}_{1}$ on neurons and $\mathrm{CB} 2$ on autoreactive T cells. Nat. Med. 13, 492-497. doi: 10.1038/nm1561
Maroso, M., Szabo, G. G., Kim, H. K., Alexander, A., Bui, A. D., Lee, S.-H., et al. (2016). Cannabinoid control of learning and memory through HCN channels. Neuron 89, 1059-1073. doi: 10.1016/j.neuron.2016. 01.023

Marsicano, G., and Kuner, R. (2008). "Anatomical distribution of receptors, ligands and enzymes in the brain and in the spinal cord: circuitries and neurochemistry," in Cannabinoids and The Brain, ed. A. Köfalvi (Boston, MA: Springer US), 161-201.

Marsicano, G., and Lutz, B. (2006). Neuromodulatory functions of the endocannabinoid system. J. Endocrinol. Invest. 29, 27-46.

Martini, L., Waldhoer, M., Pusch, M., Kharazia, V., Fong, J., Lee, J. H., et al. (2007). Ligand-induced down-regulation of the cannabinoid 1 receptor is mediated by the G-protein-coupled receptor-associated sorting protein GASP1. FASEB J. 21, 802-811. doi: 10.1096/fj.06-7132com

Di Marzo, V. (2008). Targeting the endocannabinoid system: to enhance or reduce? Nat. Rev. Drug Discov. 7, 438-455. doi: 10.1038/nrd2553

Di Marzo, V., Stella, N., and Zimmer, A. (2014). Endocannabinoid signalling and the deteriorating brain. Nat. Rev. Neurosci. 16, 30-42. doi: 10.1038/ nrn3876

McCaw, E. A., Hu, H., Gomez, G. T., Hebb, A. L. O., Kelly, M. E. M., and DenovanWright, E. M. (2004). Structure, expression and regulation of the cannabinoid receptor gene (CB1) in Huntington's disease transgenic mice. Eur. J. Biochem. 271, 4909-4920. doi: 10.1111/j.1432-1033.2004.04460.x

McDonald, N. A., Henstridge, C. M., Connolly, C. N., and Irving, A. J. (2007). An essential role for constitutive endocytosis, but not activity, in the axonal targeting of the $\mathrm{CB}_{1}$ cannabinoid receptor. Mol. Pharmacol. 71, 976-984. doi: $10.1124 / \mathrm{mol} .106 .029348$

Mechoulam, R., and Parker, L. A. (2013). The endocannabinoid system and the brain. Annu. Rev. Psychol. 64, 21-47. doi: 10.1146/annurev-psych-113011143739

Mechoulam, R., and Shohami, E. (2007). Endocannabinoids and traumatic brain injury. Mol. Neurobiol. 36, 68-74. doi: 10.1007/s12035-007-8008-6

Mievis, S., Blum, D., and Ledent, C. (2011). Worsening of Huntington disease phenotype in $\mathrm{CB}_{1}$ receptor knockout mice. Neurobiol. Dis. 42, 524-529. doi: 10. 1016/j.nbd.2011.03.006

Mukhopadhyay, S., and Howlett, A. C. (2001). CB 1 receptor-G protein association. Subtype selectivity is determined by distinct intracellular domains. Eur. J. Biochem. 268, 499-505. doi: 10.1046/j.1432-1327.2001.01810.x

Mulder, J., Zilberter, M., Pasquaré, S. J., Alpár, A., Schulte, G., Ferreira, S. G., et al. (2011). Molecular reorganization of endocannabinoid signalling in Alzheimer's disease. Brain 134, 1041-1060. doi: 10.1093/brain/awr046

Multiple sclerosis in adults: management | 1-recommendations | Guidance and guidelines | NICE. (2014). NICE. Available online at: https://www.nice.org.uk/guidance/CG186

Nguyen, P. T., Schmid, C. L., Raehal, K. M., Selley, D. E., Bohn, L. M., and SimSelley, L. J. (2012). $\beta$-arrestin2 regulates cannabinoid $\mathrm{CB}_{1}$ receptor signaling and adaptation in a central nervous system region-dependent manner. Biol. Psychiatry 71, 714-724. doi: 10.1016/j.biopsych.2011.11.027

Nie, J., and Lewis, D. L. (2001). Structural domains of the $\mathrm{CB}_{1}$ cannabinoid receptor that contribute to constitutive activity and G-protein sequestration. J. Neurosci. 21, 8758-8764.

Nobles, K. N., Xiao, K., Ahn, S., Shukla, A. K., Lam, C. M., Rajagopal, S., et al. (2011). Distinct phosphorylation sites on the $\beta_{2}$-adrenergic receptor establish a barcode that encodes differential functions of $\beta$-arrestin. Sci. Signal. 4:ra51. doi: 10.1126/scisignal.2001707

Nogueras-Ortiz, C., and Yudowski, G. A. (2016). The multiple waves of cannabinoid 1 receptor signaling. Mol. Pharmacol. 90, 620-626. doi: 10. 1124/mol.116.104539

Notcutt, W., Langford, R., Davies, P., Ratcliffe, S., and Potts, R. (2012). A placebo-controlled, parallel-group, randomized withdrawal study of subjects with symptoms of spasticity due to multiple sclerosis who are receiving long-term Sativex ${ }^{\circledR}$ (nabiximols). Mult. Scler. 18, 219-228. doi: 10. $1177 / 1352458511419700$

Otero-Romero, S., Sastre-Garriga, J., Comi, G., Hartung, H.-P., Soelberg Sørensen, P., Thompson, A. J., et al. (2016). Pharmacological management of spasticity in multiple sclerosis: systematic review and consensus paper. Mult. Scler. 22, 1386-1396. doi: 10.1177/13524585166 43600 
Ozaita, A., Puighermanal, E., and Maldonado, R. (2007). Regulation of PI3K/Akt/GSK-3 pathway by cannabinoids in the brain. J. Neurochem. 102, 1105-1114. doi: 10.1111/j.1471-4159.2007.04642.x

Palazuelos, J., Aguado, T., Pazos, M. R., Julien, B., Carrasco, C., Resel, E., et al. (2009). Microglial CB2 cannabinoid receptors are neuroprotective in Huntington's disease excitotoxicity. Brain 132, 3152-3164. doi: 10. 1093/brain/awp239

Pamplona, F. A., Ferreira, J., Menezes de Lima, O. Jr., Duarte, F. S., Bento, A. F., Forner, S., et al. (2012). Anti-inflammatory lipoxin A4 is an endogenous allosteric enhancer of $\mathrm{CB}_{1}$ cannabinoid receptor. Proc. Natl. Acad. Sci. U S A 109, 21134-21139. doi: 10.1073/pnas.1202906109

Panikashvili, D., Simeonidou, C., Ben-Shabat, S., Hanuš, L., Breuer, A., Mechoulam, R., et al. (2001). An endogenous cannabinoid (2-AG) is neuroprotective after brain injury. Nature 413, 527-531. doi: 10.1038/350 97089

Park, P. S.-H. S.-H., Lodowski, D. T., and Palczewski, K. (2008). Activation of G protein-coupled receptors: beyond two-state models and tertiary conformational changes. Annu. Rev. Pharmacol. Toxicol. 48, 107-141. doi: 10. 1146/annurev.pharmtox.48.113006.094630

Parsons, L. H., and Hurd, Y. L. (2015). Endocannabinoid signalling in reward and addiction. Nat. Rev. Neurosci. 16, 579-594. doi: 10.1038/ nrn4004

Perez, D. M., and Karnik, S. S. (2005). Multiple signaling states of G-protein-coupled receptors. Pharmacol. Rev. 57, 147-161. doi: 10.1124/pr.57. 2.2

Pertwee, R. G. (2007). Cannabinoids and multiple sclerosis. Mol. Neurobiol. 36, 45-59. doi: 10.1007/s12035-007-0005-2

Pertwee, R. G. (2015). Endocannabinoids and their pharmacological actions. Handb. Exp. Pharmacol. 231, 1-37. doi: 10.1007/978-3-319-20825-1_1

Pertwee, R. G., Howlett, A. C., Abood, M. E., Alexander, S. P. H., Di Marzo, V., Elphick, M. R., et al. (2010). International union of basic and clinical pharmacology. LXXIX. Cannabinoid receptors and their ligands: beyond $\mathrm{CB}_{1}$ and $\mathrm{CB}_{2}$. Pharmacol. Rev. 62, 588-631. doi: 10.1124/pr.110. 003004

Prihandoko, R., Alvarez-Curto, E., Hudson, B. D., Butcher, A. J., Ulven, T., Miller, A. M., et al. (2016). Distinct phosphorylation clusters determine the signaling outcome of free fatty acid receptor $4 / G$ protein-coupled receptor 120. Mol. Pharmacol. 89, 505-520. doi: 10.1124/mol.115. 101949

Pryce, G., Ahmed, Z., Hankey, D. J. R., Jackson, S. J., Croxford, J. L., Pocock, J. M., et al. (2003). Cannabinoids inhibit neurodegeneration in models of multiple sclerosis. Brain 126, 2191-2202. doi: 10.1093/brain/awg224

Ramírez, B. G., Blázquez, C., Gómez del Pulgar, T. G., Guzmán, M., and de Ceballos, M. L. (2005). Prevention of Alzheimer's disease pathology by cannabinoids: neuroprotection mediated by blockade of microglial activation. J. Neurosci. 25, 1904-1913. doi: 10.1523/JNEUROSCI.454004.2005

Roche, J. P., Bounds, S., Brown, S., and Mackie, K. (1999). A mutation in the second transmembrane region of the $\mathrm{CB}_{1}$ receptor selectively disrupts $\mathrm{G}$ protein signaling and prevents receptor internalization. Mol. Pharmacol. 56, 611-618. doi: 10.1124/mol.56.3.611

Rog, D. J. (2010). Cannabis-based medicines in multiple sclerosis-a review of clinical studies. Immunobiology 215, 658-672. doi: 10.1016/j.imbio.2010.03.009

Rozenfeld, R. (2011). Type I cannabinoid receptor trafficking: all roads lead to lysosome. Traffic 12, 12-18. doi: 10.1111/j.1600-0854.2010. 01130.x

Rozenfeld, R., and Devi, L. A. (2008). Regulation of $\mathrm{CB}_{1}$ cannabinoid receptor trafficking by the adaptor protein AP-3. FASEB J. 22, 2311-2322. doi: 10 . 1096/fj.07-102731

Rueda, D., Galve-Roperh, I., Haro, A., and Guzmán, M. (2000). The $\mathrm{CB}_{1}$ cannabinoid receptor is coupled to the activation of c-Jun N-terminal kinase. Mol. Pharmacol. 58, 814-820. doi: 10.1124/mol.58.4.814

Sagredo, O., García-Arencibia, M., de Lago, E., Finetti, S., Decio, A., and Fernández-Ruiz, J. (2007). Cannabinoids and neuroprotection in basal ganglia disorders. Mol. Neurobiol. 36, 82-91. doi: 10.1007/s12035-007-0004-3

Saito, V. M., Rezende, R. M., and Teixeira, A. L. (2012). Cannabinoid modulation of neuroinflammatory disorders. Curr. Neuropharmacol. 10, 159-166. doi: 10. 2174/157015912800604515
Scotter, E. L., Abood, M. E., and Glass, M. (2010). The endocannabinoid system as a target for the treatment of neurodegenerative disease. Br. J. Pharmacol. 160, 480-498. doi: 10.1111/j.1476-5381.2010.00735.x

Shohami, E., Cohen-Yeshurun, A., Magid, L., Algali, M., and Mechoulam, R. (2011). Endocannabinoids and traumatic brain injury. Br. J. Pharmacol. 163, 1402-1410. doi: 10.1111/j.1476-5381.2011.01343.x

Soltesz, I., Alger, B. E., Kano, M., Lee, S.-H., Lovinger, D. M., Ohno-Shosaku, T., et al. (2015). Weeding out bad waves: towards selective cannabinoid circuit control in epilepsy. Nat. Rev. Neurosci. 16, 264-277. doi: 10.1038/ nrn3937

Stempel, A. V., Stumpf, A., Zhang, H. Y., Özdogan, T., Pannasch, U., Theis, A. K., et al. (2016). Cannabinoid type 2 receptors mediate a cell type-specific plasticity in the hippocampus. Neuron 90, 795-809. doi: 10.1016/j.neuron.2016. 03.034

Straiker, A., and Mackie, K. (2005). Depolarization-induced suppression of excitation in murine autaptic hippocampal neurones. J. Physiol. 569, 501-517. doi: 10.1113/jphysiol.2005.091918

Straiker, A., Wager-Miller, J., Hutchens, J., and Mackie, K. (2012). Differential signalling in human cannabinoid $\mathrm{CB}_{1}$ receptors and their splice variants in autaptic hippocampal neurones. Br. J. Pharmacol. 165, 2660-2671. doi: 10. $1111 / j .1476-5381.2011 .01744 . x$

Stumm, C., Hiebel, C., Hanstein, R., Purrio, M., Nagel, H., Conrad, A., et al. (2013). Cannabinoid receptor 1 deficiency in a mouse model of Alzheimer's disease leads to enhanced cognitive impairment despite of a reduction in amyloid deposition. Neurobiol. Aging 34, 2574-2584. doi: 10.1016/j.neurobiolaging. 2013.05.027

Thomsen, A. R. B., Plouffe, B., Cahill, T. J. III., Shukla, A. K., Tarrasch, J. T., Dosey, A. M., et al. (2016). GPCR-G protein- $\beta$-arrestin super-complex mediates sustained G protein signaling. Cell 166, 907-919. doi: 10.1016/j.cell. 2016.07.004

Trazzi, S., Steger, M., Mitrugno, V. M., Bartesaghi, R., and Ciani, E. (2010). $\mathrm{CB}_{1}$ cannabinoid receptors increase neuronal precursor proliferation through AKT/glycogen synthase kinase-3 $\beta / \beta$-catenin signaling. J. Biol. Chem. 285, 10098-10109. doi: 10.1074/jbc.M109.043711

Twitchell, W., Brown, S., and Mackie, K. (1997). Cannabinoids inhibit N-and P/Qtype calcium channels in cultured rat hippocampal neurons. J. Neurophysiol. 78 , 43-50.

Valdeolivas, S., Satta, V., Pertwee, R. G., Fernández-Ruiz, J., and Sagredo, O. (2012). Sativex-like combination of phytocannabinoids is neuroprotective in malonate-lesioned rats, an inflammatory model of Huntington's disease: role of $\mathrm{CB}_{1}$ and $\mathrm{CB}_{2}$ receptors. ACS Chem. Neurosci. 3, 400-406. doi: 10. $1021 / \mathrm{cn} 200114 \mathrm{w}$

Vallée, M., Vitiello, S., Bellocchio, L., Hébert-Chatelain, E., Monlezun, S., MartinGarcia, E., et al. (2014). Pregnenolone can protect the brain from cannabis intoxication. Science 343, 94-98. doi: 10.1126/science.1243985

Varga, E. V., Georgieva, T., Tumati, S., Alves, I., Salamon, Z., Tollin, G., et al. (2008). Functional selectivity in cannabinoid signaling. Curr. Mol. Pharmacol. 1, 273-284. doi: 10.2174/1874-470210801030273

Varvel, S. A., Martin, B. R., and Lichtman, A. H. (2007). Lack of behavioral sensitization after repeated exposure to THC in mice and comparison to methamphetamine. Psychopharmacology (Berl) 193, 511-519. doi: 10 1007/s00213-007-0811-2

Wade, D. T., Collin, C., Stott, C., and Duncombe, P. (2010). Meta-analysis of the efficacy and safety of Sativex (nabiximols), on spasticity in people with multiple sclerosis. Mult. Scler. 16, 707-714. doi: 10.1177/13524585103 67462

Wilson, R. I., and Nicoll, R. A. (2001). Endogenous cannabinoids mediate retrograde signalling at hippocampal synapses. Nature 410, 588-592. doi: 10 . 1038/35069076

Wu, D.-F., Yang, L.-Q., Goschke, A., Stumm, R., Brandenburg, L.-O., Liang, Y.-J., et al. (2008). Role of receptor internalization in the agonist-induced desensitization of cannabinoid type 1 receptors. J. Neurochem. 104, 1132-1143. doi: 10.1111/j.1471-4159.2007.05063.x

Xi, Z.-X., Peng, X.-Q., Li, X., Song, R., Zhang, H.-Y., Liu, Q.-R., et al. (2011). Brain cannabinoid CB2 receptors modulate cocaine's actions in mice. Nat. Neurosci. 14, 1160-1166. doi: 10.1038/nm.2483

Yeh, F. L., Wang, Y., Tom, I., Gonzalez, L. C., and Sheng, M. (2016). TREM2 binds to apolipoproteins, including APOE and CLU/APOJ and thereby facilitates 
uptake of amyloid- $\beta$ by microglia. Neuron $91,328-340$. doi: 10.1016/j.neuron. 2016.06.015

Zhang, H.-Y., Gao, M., Shen, H., Bi, G.-H., Yang, H.-J., Liu, Q.-R., et al. (2016). Expression of functional cannabinoid CB2 receptor in VTA dopamine neurons in rats. Addict. Biol. doi: 10.1111/adb.12367 [Epub ahead of print].

Zimmer, A., Zimmer, A. M., Hohmann, A. G., Herkenham, M., and Bonner, T. I. (1999). Increased mortality, hypoactivity and hypoalgesia in cannabinoid $\mathrm{CB}_{1}$ receptor knockout mice. Proc. Natl. Acad. Sci. U S A 96, 5780-5785. doi: 10. 1073/pnas.96.10.5780
Conflict of Interest Statement: The authors declare that the research was conducted in the absence of any commercial or financial relationships that could be construed as a potential conflict of interest.

Copyright $\odot 2017$ Kendall and Yudowski. This is an open-access article distributed under the terms of the Creative Commons Attribution License (CC BY). The use, distribution and reproduction in other forums is permitted, provided the original author(s) or licensor are credited and that the original publication in this journal is cited, in accordance with accepted academic practice. No use, distribution or reproduction is permitted which does not comply with these terms. 